\title{
Differences in Trace Element Content between Non-Indigenous Farmed and Invasive Bivalve Mollusks of the South African Coast
}

\author{
Dmitry F. Pavlov ${ }^{1}$, Jacques Bezuidenhout ${ }^{2}$, Marina V. Frontasyeva ${ }^{3 *}$, Zoya I. Goryainova ${ }^{3}$ \\ ${ }^{1}$ I. D. Papanin Institute of the Biology of Inland Waters, Borok, Russian Federation \\ ${ }^{2}$ Faculty of Military Science, Physics Department, Stellenbosch University, Saldanha, South Africa \\ ${ }^{3}$ Joint Institute for Nuclear Research, Moscow Region, Russian Federation \\ Email: ${ }^{*}$ marina@nf.jinr.ru
}

Received 2 August 2015; accepted 18 October 2015; published 21 October 2015

Copyright (C) 2015 by authors and Scientific Research Publishing Inc.

This work is licensed under the Creative Commons Attribution International License (CC BY). http://creativecommons.org/licenses/by/4.0/

(c) (i) Open Access

\begin{abstract}
The contents of 23 trace elements (Sc, V, Cr, Mn, Fe, Co, Zn, As, Se, Br, Rb, Sr, Mo, Ag, Sb, I, Ba, La, Ce, $\mathrm{Sm}, \mathrm{Eu}, \mathrm{Hf}, \mathrm{Ta})$ were quantitatively determined in soft tissues and shells of mass non-indigenous bivalve mussels-farmed Pacific oysters (Crassostrea gigas) and farmed and wild invasive Mediterranean mussels (Mytilus galloprovincialis) at the Atlantic coast of South Africa. The study revealed that the contents of the majority of elements in the soft tissues of both species were higher than those in the shells. The tissues of wild invasive Mediterranean mussels contain higher levels of a range of trace elements comparing to farmed mussels. The tissues of Pacific oysters contain much higher levels of almost all elements studied compared to the tissues of Mediterranean mussels. Higher content of zinc in the mussels and oysters from Saldanha Bay may evidence anthropogenic pollution of the bay's ecosystem by this metal, which necessitates continued monitoring of levels of potentially toxic metals. Both alien species, and especially Pacific oysters, may serve as reliable biomonitors for trace elements in marine ecosystems. Both species are rich in essential elements and provide nutritionally-valuable seafoods.
\end{abstract}

\section{Keywords}

Invasive Bivalve Mollusks, Chemical Composition, Crassostrea gigas, Mytilus galloprovincialis, Aquaculture, Water Quality, South Africa

\footnotetext{
${ }^{*}$ Corresponding author.
} 


\section{Introduction}

Aquaculture becomes a very important branch of economic activity worldwide. A number of species are propagated at the marine farms in South Africa. The roles of Pacific oyster (Crassostrea gigas) and Mediterranean mussel (Mytilus galloprovincialis) are especially noticeable. Pacific oyster was introduced to the Knysna Estuary in South Africa in the 1950s with the intention to use them for farming [1]. Mediterranean mussel has been commercially grown in Saldanha Bay since 1987 [Van Erkom Schurink and Griffiths, 1990], and the annual yield of mussels (primarily M. galloprovincialis) varies between approximately 500 and 3000 tons per annum [Anonymous, 2001]. In 2010 there were six operational oyster farms in the Western Cape and five in the Eastern Cape [2]. The total 2011 production of oysters in South Africa was around 270 thousand metric tons [1]. Saldanha Bay of the South African Atlantic coast represents an area of intensive mollusk farming: the shellfish farms are covering 345 ha, or about $8 \%$ of the entire bay's area and are playing a growing role for the local economy [3].

The aquaculture may be considered as a peculiar form of biological invasion. As opposite to farming of caged terrestrial animals having rather limited and manageable impact upon environment, in most cases the organisms propagated at marine farms are "inserted" in the environment and affect it directly. The exometabolites of farmed organisms along with commensals, parasites and pathogens associated with these organisms enter the host aquatic ecosystems and may cause various effects: water eutrophication, increased sedimentation of suspended matter causing deterioration of conditions for indigenous benthic organisms in the zones of farming, competition for forage with other aquatic species (e.g. commercially valuable indigenous fish), introduction and dispersal of pathogens, biological invasions, etc. [4]-[7].

The farmed organisms themselves escaping the marine farms may become invaders. In South Africa Mediterranean mussel introduced for farming gives an example of one of the most aggressive and successful aliens. This species was introduced on the west coast of South Africa in the late 1970s or early 1980s [8]. Since that time the introduced Mediterranean mussel has successfully invaded the southern African coastline and has become the dominant species on rocky intertidal shores of the west coast with population covering $2050 \mathrm{~km}$ of South African shores [9] [10]. For example, in Langebaan Lagoon of the South African west coast the littoral mussel populations comprised almost exclusively (99\%) of M. galloprovincialis [9]. The invasion and establishing of Mediterranean mussel caused significant ecological impacts including the competitive displacement of indigenous species and a dramatic increase in intertidal mussel biomass [10]. Intensively farmed Pacific oyster has appeared unable to complete its life cycle under local environmental conditions and thus was considered to be a species having limited invasive potential in South African coastal waters [8]. However, later on sustainable and selfreproducible populations of this species were found along the South Coast and populations were documented in the Breede, Goukou and Knysna estuaries [10].

As one of the less obvious and poorly studied but potentially important environmental consequences of biological invasions is the modification of biogeochemical cycling of chemical elements including heavy metals (HM) and rare earth elements (REE) in the aquatic ecosystems. This may also affect the water quality or, more generally, the quality of aquatic ecosystems.

Bivalve mollusks are filter-feeders. It was revealed that Pacific oysters could filter water at a rate of 5 to 25 l/g body weight/h [11]. Mass production of farmed oysters and mussels suggests considerable impact of these organisms upon biogeochemical cycling of elements and environmental quality in the areas subject to effects by mariculture. The scale of this impact has not been estimated yet. The determination of the levels of chemical elements accumulated in the farmed mollusks along with those removed from the environment at harvesting of "wild invasive" mollusks may serve as an initial step in elucidating the balance of chemical elements in the aquatic environment modified by aquaculture-related biological invasions.

The clarification of the latter possible effect of farmed and/or wild invasive mollusk species requires the analysis of the patterns and regularities in accumulation of various chemical elements (heavy metals (HM) and rare earth elements (REE), in particular) in such species. In this respect studies on the cycling of REE could be especially valuable in relation to general understanding of the chemical functioning of the elements in the hydrosphere since these elements provide good tracers for examining a number of geochemical processes [12]. REE, considered by some researchers as HM [13], are characterized by increasing technical application. Hence, environmental emissions of REE need to be monitored. This demands development of adequate monitoring approaches, selection of biomonitors and adequate analytic techniques [14]. 
Instrumental neutron activation analysis (INAA) is a powerful tool giving an opportunity to determine the contents of a number of chemical elements in a small single sample. In addition, such analysis may provide information on the usefulness of farmed and invasive wild bivalve mollusks as indicator species for monitoring of anthropogenic pollution. This refers to the development and continuation of a system of environmental monitoring following the "Mussel Watch" (MW) approach utilizing the ability of bivalve mollusks to accumulate a range of potentially hazardous environmental pollutants [15], Goldberg, 1975; [16] [17]. For South Africa continuing of MW program with use of modern analytical techniques is a topical issue since the country has many potential sources of pollution (e.g. intensive and growing mining, ore processing industries, and well developed sea transport facilities) which may negatively affect a range of economically-important activities.

The main goal of the present paper is to determine quantitatively using INAA the contents of trace elements in the bivalve mollusks, farmed and wild Mediterranean mussels and farmed Pacific oysters of the Atlantic west coast of Republic of South Africa (Saldanha and Danger bays). The obtained data will serve 1) for further assessment of removal of chemical elements with harvesting of farmed and wild invasive mollusks and 2) as an initial step for drawing the biogeochemical balance and the assessment of importance of introduction of alien species for modification of biogeochemical cycling of elements and changes in water quality associated with introduction of non-indigenous bivalve mollusks. In other words, the study contributes to the understanding of the biogeochemical role of biological invasions in aquatic systems.

\section{Materials and Methods}

\subsection{Sampling and Sample Preparation}

Sampling sites for the bivalve mollusks studied under present study were situated at the South African Atlantic coast (Figure 1).

Two species of marine bivalve mollusks farmed in sea water were sampled and analyzed: Pacific oyster (Crassostrea gigas) and Mediterranean mussel (Mytilus galloprovincialis). In addition we analyzed the wild Mediterranean mussels from the naturalized population in Danger Bay. The dates of sampling and locations of sampling sites are given in Table 1.

Ten specimens of both species were sampled from each site, sealed in zip-locked plastic bags, refrigerated, and shipped for further processing and subjecting to neutron activation analysis [18].

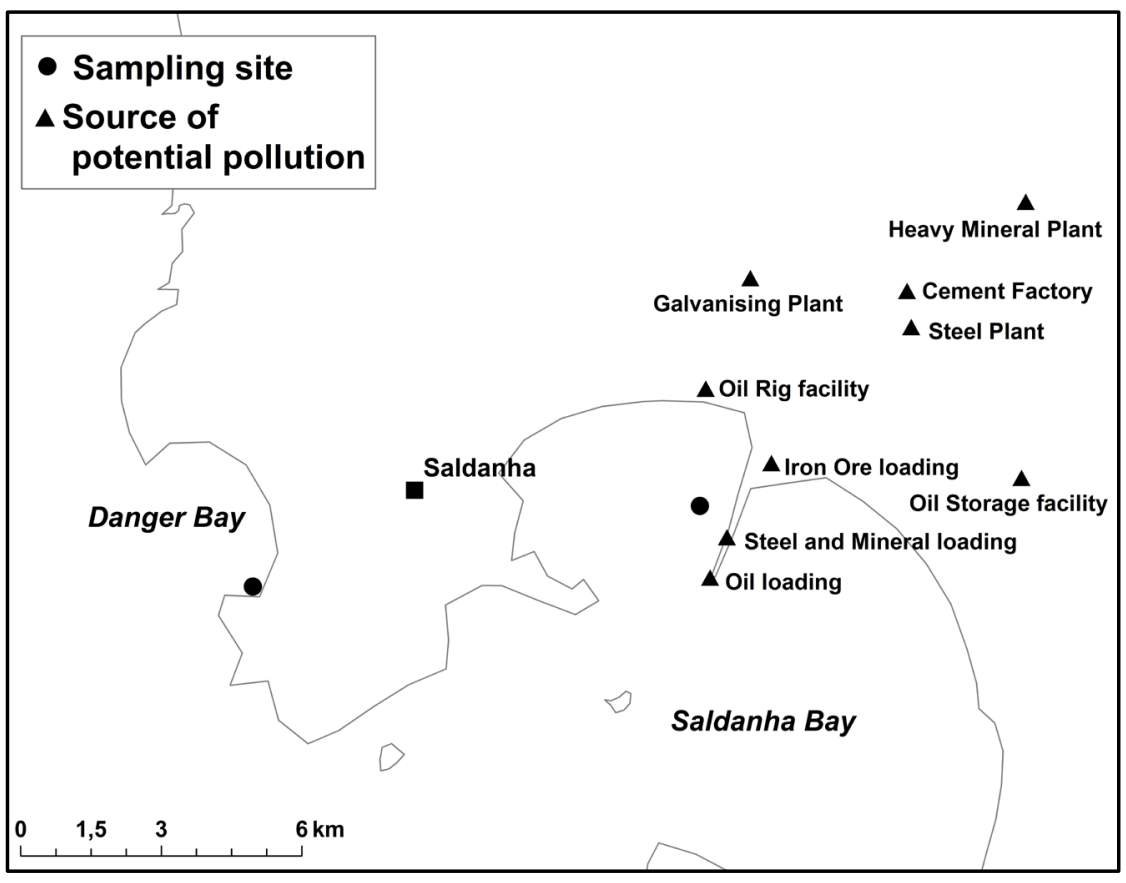

Figure 1. Map of the studied area (the dot in the Saldanha Bay is the farm of West Coast Aquaculture). 
Table 1. Species, locations and dates of mollusk sampling.

\begin{tabular}{|c|c|c|c|}
\hline Species & Location of sampling & Geographical coordinates & Date of sampling \\
\hline Mediterranean mussel (Mytilus galloprovincialis) & $\begin{array}{l}\text { "West Coast Aquaculture Aqua } \\
\text { farm", Saldanha Bay }\end{array}$ & $\begin{array}{l}33^{\circ} 00^{\prime} 39^{\prime \prime S} \\
17^{\circ} 58^{\prime} 31^{\prime \prime} \mathrm{E}\end{array}$ & July 30, 2012 \\
\hline Mediterranean mussel (Mytilus galloprovincialis) & Danger Bay & $33^{\circ} 1^{\prime} 45^{\prime \prime S}, 17^{\circ} 53^{\prime} 47^{\prime \prime E}$ & August 17, 2012 \\
\hline Pacific oyster (Crassostrea gigas) & $\begin{array}{l}\text { "West Coast Aquaculture Aqua } \\
\text { farm", Saldanha Bay }\end{array}$ & $\begin{array}{l}33^{\circ} 00^{\prime} 39^{\prime \prime S} \\
17^{\circ} 58^{\prime} 31^{\prime \prime} \mathrm{E}\end{array}$ & September, 2012 \\
\hline
\end{tabular}

In the laboratory the mollusks were dissected, soft tissues separated from the shells and the samples were dried at $39^{\circ} \mathrm{C}$ to a constant weight prior to further processing. The latter included homogenization of dried samples in ball grinder and packing in appropriate containers for irradiation.

\subsection{Analysis}

INAA was performed in the radioanalytical laboratory at the pulsed fast reactor IBR-2, FLNP JINR. To determine short-lived isotopes of $\mathrm{Cl}, \mathrm{Br}$, and I samples of $0.3 \mathrm{~g}$ were packed in polyethylene bags and irradiated for 3 - $5 \mathrm{~min}$ in an irradiation channel with neutron flux density $\Phi_{\text {epi }}=1.3 \times 10^{12} \mathrm{n} /\left(\mathrm{cm}^{2} \times \mathrm{s}\right)$.

Gamma spectra of induced activity were measured twice, for $3-5$ min after 5 - 7 minutes of decay and for 10 - 15 min after 20 min of decay. To process gamma spectra and to calculate concentrations of elements, software developed at FLNP JINR was applied [19].

Quality control was provided by analyzing relevant certified reference materials. Results were assessed statistically by the Student's t-test at 0.5 significance level.

\section{Results and Discussion}

Data on the contents of 23 trace elements (Sc, V, Cr, Mn, Fe, Co, Zn, As, Se, Br, Rb, Sr, Mo, Ag, Sb, I, Ba, La, $\mathrm{Ce}, \mathrm{Sm}, \mathrm{Eu}, \mathrm{Hf}, \mathrm{Ta})$ quantitatively determined in soft tissues and shells of bivalve mussels are given in Table 2.

Mediterranean mussels. The contents of REE (La, Ce, Sm, Eu), hafnium and tantalum in shells and soft tissues of Mediterranean mussels from both sampling sites were below detection limits. In the mussel soft tissues the levels of such metals as vanadium (Danger Bay), antimony and barium (both sampling sites) were also below detection limits. The same applies to selenium, rubidium and molybdenum in the shells of mussels from both sites. A majority of the studied trace elements were higher in the mussel soft tissue than in the shells. However, higher shell contents were revealed for vanadium (below detection limit in the soft tissues versus 0.5 $\pm 0.08 \mathrm{mg} / \mathrm{kg}$ in the shells in the Danger Bay and similar tissue levels in the Saldanha Bay mussels), strontium (958 $\pm 31 \mathrm{mg} / \mathrm{kg}$ in Danger Bay and $806 \pm 12 \mathrm{mg} / \mathrm{kg}$ in Saldanha Bay versus $88 \pm 1.4 \mathrm{mg} / \mathrm{kg}$ and $18.5 \pm 0.9$ $\mathrm{mg} / \mathrm{kg}$, respectively), antimony (the contents in the mussel soft tissues were below $0.05 \mathrm{mg} / \mathrm{kg}$ while in the shells they were $0.02 \pm 0.003 \mathrm{mg} / \mathrm{kg}$ in Danger Bay and $0.03 \pm 0.007 \mathrm{mg} / \mathrm{kg}$ in Saldanha Bay), barium (below detection limits $0.5 \mathrm{mg} / \mathrm{kg}$ in the soft tissues versus $4.7 \pm 0.6 \mathrm{mg} / \mathrm{kg}$ in the Danger Bay mussel shells and $4.3 \pm$ $0.1 \mathrm{mg} / \mathrm{kg}$ in the Saldanha Bay mussel shells), manganese (258 $\pm 5 \mathrm{mg} / \mathrm{kg}$ in the shells versus $194 \pm 4 \mathrm{mg} / \mathrm{kg}$ in the soft tissues) and bromine (94 $\pm 0.4 \mathrm{mg} / \mathrm{kg}$ in the soft tissues versus $110 \pm 3 \mathrm{mg} / \mathrm{kg}$ in the shells) in the Saldanha Bay mussels (Table 2).

Comparison of trace element contents in the farmed (Saldanha Bay) and wild (Danger Bay) mussels revealed differences in some element concentrations both in the shells and soft tissues.

The concentrations of the metals cobalt, manganese and antimony as well as the halogens bromine and iodine were significantly higher in the shells of the Mediterranean mussels from Saldanha Bay; of strontium, from the Danger Bay. Similar trend towards higher shell contents in the Saldanha Bay mussels were apparent for chromium, iron and arsenic but the differences were not statistically significant (Table 2). Shell concentrations of scandium, vanadium and barium were higher in Danger Bay than in Saldanha Bay but the differences were insignificant.

The mussel soft tissue element contents exhibited different patterns. As opposite to the shells, the soft tissues of the mussels from the Danger Bay contained significantly higher levels of most of the elements determined (Cr, $\mathrm{Mn}, \mathrm{Sr}, \mathrm{Mo}, \mathrm{Ag}, \mathrm{Fe}, \mathrm{Co}, \mathrm{Br}$ and I); the differences between the levels of As, Se, Rb, Ba were statistically insignificant; the contents of Sc and Zn were significantly higher in the mussels from Saldanha Bay (Table 2; Figure 2). 
Table 2. Contents of trace elements in Mediterranean mussels and Pacific oysters of South African Atlantic coast.

\begin{tabular}{|c|c|c|c|c|c|c|}
\hline \multirow{4}{*}{ Element } & \multicolumn{6}{|c|}{ Content of chemical elements, $\mathrm{mg} / \mathrm{kg}$ dry weight ${ }^{*}$} \\
\hline & \multirow{2}{*}{\multicolumn{2}{|c|}{$\begin{array}{c}\text { Danger Bay } \\
\text { Mediterranean mussel }\end{array}$}} & \multicolumn{4}{|c|}{ Saldanha Bay } \\
\hline & & & \multicolumn{2}{|c|}{ Mediterranean mussel } & \multicolumn{2}{|c|}{ Pacific oyster } \\
\hline & Soft tissue & Shell & Soft tissue & Shell & Soft tissue & Shell \\
\hline Sc & $0.008 \pm 0.001^{1}$ & $0.004 \pm 0.001$ & $0.02 \pm 0.002^{1.3}$ & $0.002 \pm 0.0004$ & $0.02 \pm 0.002$ & $0.12 \pm 0.007^{1.4}$ \\
\hline $\mathrm{V}$ & $<$ det. lim. & $0.5 \pm 0.08^{1}$ & $0.3 \pm 0.04$ & $0.3 \pm 0.1$ & 0.3 & $0.7 \pm 0.03^{1.4}$ \\
\hline $\mathrm{Cr}$ & $1.6 \pm 0.2^{1.3}$ & $0.5 \pm 0.08$ & $1.03 \pm 0.2$ & $0.6 \pm 0.1$ & $2.5 \pm 0.5^{1.5}$ & $1.2 \pm 0.06^{4}$ \\
\hline Mn & $321 \pm 22^{1.3}$ & $81 \pm 1.9$ & $194 \pm 4$ & $258 \pm 5^{1.2 .4}$ & $829 \pm 24^{1.5}$ & $17 \pm 0.9$ \\
\hline $\mathrm{Fe}$ & $178 \pm 12^{1.3}$ & $66 \pm 8$ & $134 \pm 2$ & $73 \pm 3$ & $412 \pm 36^{1.5}$ & $313 \pm 10^{4}$ \\
\hline Co & $15.4 \pm 0.5^{1.3}$ & $1.6 \pm 0.05$ & $12.8 \pm 0.1$ & $4.7 \pm 0.2^{2.4}$ & $112 \pm 7.3^{1.5}$ & $0.2 \pm 0.02$ \\
\hline $\mathrm{Zn}$ & $96 \pm 3^{1}$ & $1.5 \pm 0.5$ & $108 \pm 0.7^{3}$ & $1.5 \pm 0.1$ & $476 \pm 7^{1.5}$ & $9.6 \pm 0.6^{4}$ \\
\hline As & $5.2 \pm 0.51$ & $0.2 \pm 0.03$ & $6.0 \pm 0.07$ & $0.3 \pm 0.07$ & $7.7 \pm 0.6^{1.5}$ & 0.293 \\
\hline Se & $1.3 \pm 0.1^{1}$ & <det. lim. & $1.3 \pm 0.09$ & <det. lim. & $1.5 \pm 0.009^{5}$ & <det. lim. \\
\hline $\mathrm{Br}$ & $148 \pm 5.5^{1.3}$ & $33 \pm 0.5$ & $94 \pm 0.4$ & $110 \pm 3^{1.2 .4}$ & $127 \pm 9.5^{1.5}$ & $25 \pm 0.9$ \\
\hline $\mathrm{Rb}$ & $4 \pm 0.05^{1}$ & <det. lim. & $3.9 \pm 0.2^{5}$ & <det. lim. & $2.1 \pm 0.3^{1.5}$ & $1.1 \pm 0.1^{4}$ \\
\hline $\mathrm{Sr}$ & $88 \pm 1.4^{2.3}$ & $958 \pm 31^{1}$ & $18.5 \pm 0.9$ & $806 \pm 12^{1}$ & $45 \pm 5.0^{5}$ & $762 \pm 25^{1}$ \\
\hline Mo & $1.4 \pm 0.3^{1.3}$ & <det. lim. & $0.6 \pm 0.09$ & $<$ det. lim. & $0.8 \pm 0.09^{1.5}$ & $<$ det. lim. \\
\hline $\mathrm{Ag}$ & $0.09 \pm 0.04^{1.3}$ & $0.02 \pm 0.004$ & $0.06 \pm 0.008$ & <det. lim. & $0.2 \pm 0.01^{1.5}$ & 0.04 \\
\hline $\mathrm{Sb}$ & <det. lim. & $0.02 \pm 0.003^{1}$ & <det. lim. & $0.03 \pm 0.007^{1.2}$ & <det. lim. & $0.02 \pm 0.003^{1}$ \\
\hline I & $5.6 \pm 0.1^{1.3}$ & $4.2 \pm 0.2$ & $4.3 \pm 0.06$ & $8.3 \pm 0.2^{2}$ & $10.9 \pm 0.4^{5}$ & $11.6 \pm 0.6^{4}$ \\
\hline $\mathrm{Ba}$ & < det. lim. & $4.7 \pm 0.61^{1}$ & < det. lim. & $4.3 \pm 0.1^{1}$ & $<$ det. lim. & $4.1 \pm 1.7^{1}$ \\
\hline $\mathrm{La}$ & <det. lim. & <det. lim. & $<$ det. lim. & $<$ det. lim. & $<$ det. lim. & $0.6 \pm 0.03^{1.4}$ \\
\hline $\mathrm{Ce}$ & $<$ det. lim. & $<$ det. lim. & $<$ det. lim. & $<$ det. lim. & $<$ det. lim. & $1.0 \pm 0.05^{1.4}$ \\
\hline $\mathrm{Sm}$ & <det. lim. & <det. lim. & <det. lim. & <det. lim. & <det. lim. & $0.08 \pm 0.004^{1.4}$ \\
\hline $\mathrm{Eu}$ & <det. lim. & <det. lim. & <det. lim. & <det. lim. & <det. lim. & $0.009 \pm 0.001^{1.4}$ \\
\hline $\mathrm{Hf}$ & $<$ det. lim. & < det. lim. & <det. lim. & < det. lim. & $0.04 \pm 0.006^{5}$ & $0.03 \pm 0.004$ \\
\hline $\mathrm{Ta}$ & $<$ det. lim. & $<$ det. lim. & $<$ det. lim. & $<$ det. lim. & $<$ det. lim. & $0.01 \pm 0.001^{1.4}$ \\
\hline
\end{tabular}

*Mean values and standard errors are given. < det. lim.- determined values are below the detection limit. Figures superscript denote statistically significantly higher levels of elements at the comparison of: ${ }^{1}$ Soft tissues versus shells; ${ }^{2}$ Mussel shells in Danger Bay versus Saldanha Bay; ${ }^{3}$ Mussel soft tissues in Danger Bay versus Saldanha Bay; ${ }^{4}$ Shells in mussels versus oysters (Saldanha Bay); ${ }^{5}$ Soft tissues in mussels versus oysters (Saldanha Bay).

Pacific oysters. In Pacific oysters the contents of selenium and molybdenum in the shells as well as of antimony, barium, lanthanides ( $\mathrm{La}, \mathrm{Ce}, \mathrm{Sm}$, and $\mathrm{Eu}$ ) and tantalum in the soft tissues were below the respective detection limits (Table 2).

The soft tissues of Pacific oysters farmed in Saldanha Bay contained significantly more chromium, manganese, iron, cobalt, zinc, arsenic, selenium, bromine, rubidium, molybdenum, and silver than the shells. The contents of scandium, vanadium, strontium, antimony and barium were higher in the shells; the differences in the iodine contents were statistically insignificant (Table 2). As opposite to the Mediterranean mussels, the lanthanides ( $\mathrm{La}, \mathrm{Ce}, \mathrm{Sm}, \mathrm{Eu}$ ) and tantalum, were found at detectable levels in the shells, and hafnium both in the shells and soft tissues (in this case the differences were insignificant). That is, the shells of Pacific oysters contained much higher levels of lanthanides and tantalum than the soft tissues (Table 2).

Mediterranean mussels versus Pacific oysters. As noted above we revealed site-specific differences in the contents of some elements in Mediterranean mussels. This is why we compare contents of trace elements in the 


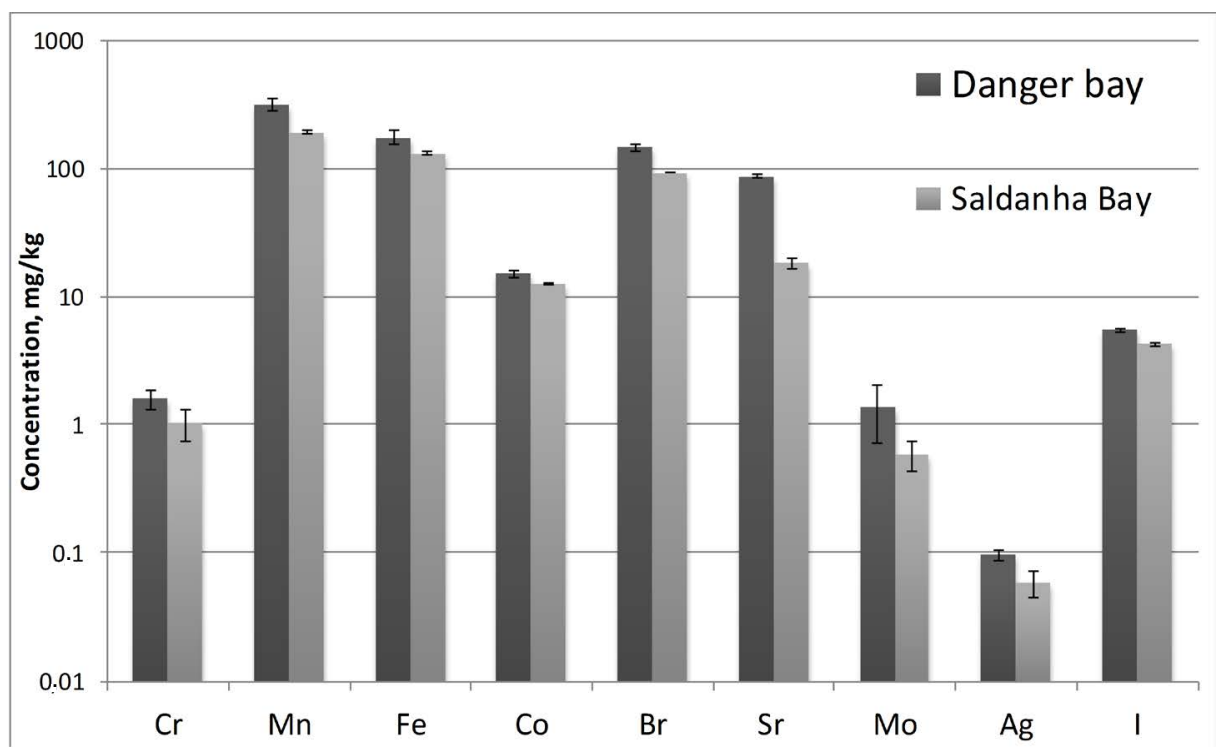

Figure 2. Contents of chemical elements in the soft tissues of Mediterranean mussels from Danger and Saldanha bays (mg/kg). Logarithmic scale; mean and standard deviations are shown.

oysters and mussels from the same location (Saldanha Bay) only.

The contents of most elements: Sc, V, Cr, Fe, Zn, Rb, and Ta), lanthanides (La, Ce, Sm, and Eu) and iodine were significantly higher in the shells of Pacific oysters than of Mediterranean mussels; the shell levels of manganese, cobalt and bromine were higher in the mussels; the concentrations of arsenic, antimony, barium and hafnium did not differ significantly (Table 2).

A similar picture is apparent when comparing levels of trace elements in the shellfish soft tissues (Table 2). The contents of almost all elements determined (Cr, Mn, Fe, Co, Zn, As, Se, Br, Rb, Sr, Mo, Ag, I, and Hf) were higher in the oyster soft tissues (Figure 3). An exception was rubidium, which was significantly higher in the mussel soft tissues. Differences between the concentrations of scandium and vanadium were insignificant.

Data on element contents (including trace elements) in mussels and oysters have been presented in many papers published earlier [20]-[24], etc. However, the majority of such papers deal with the contents of only a few elements belonging to the heavy metals group. The data on most other elements are rather limited and mainly deal with mollusk physiology (see e.g. [25]). Many related issues, such as ecological importance of accumulation of trace elements by mollusks, are still obscure.

The overall goal of most of the above papers was to assess the potential harm of elements accumulated in the mussels and oysters for the well-being of their populations and for the health of humans consuming the mollusks. This applies both for farmed and wild bivalve mollusks that are harvested and used as seafood. For instance, to ensure purchase of healthy mariculture products the system of quality monitoring in South Africa was developed. In the Republic of South Africa the oyster farmers are required to sample animal tissues and water in the culture area, to be tested by accredited laboratories as part of the "South African Molluscan Shellfish Monitoring and Control Program" administered by the national Department of Agriculture, Forestry and Fisheries (DAFF). Several parameters are monitored on a regular basis: microbiological status, presence and/or content of biotoxins, and contents of potentially harmful xenobiotics such as persistent organic pollutants and heavy metals [2]. However the routine monitoring of trace elements includes only a limited number of elements such as cadmium, lead, arsenic, and mercury. The contents of other elements are usually not monitored. This concerns not only potentially hazardous HM but also so-called "essential elements" or "micronutrients" (MN). The concept of "food quality" should consider not only the content of potentially hazardous elements but also the concentrations of the nutritionally valuable components, including essential elements. The content of these elements is an important issue, determining to a great extent the nutritional value of seafood. The problems related to the impact of mariculture and commercially valuable invasive mollusks upon chemical cycling in the affected ecosystems are not covered by the existing system of chemical monitoring. 


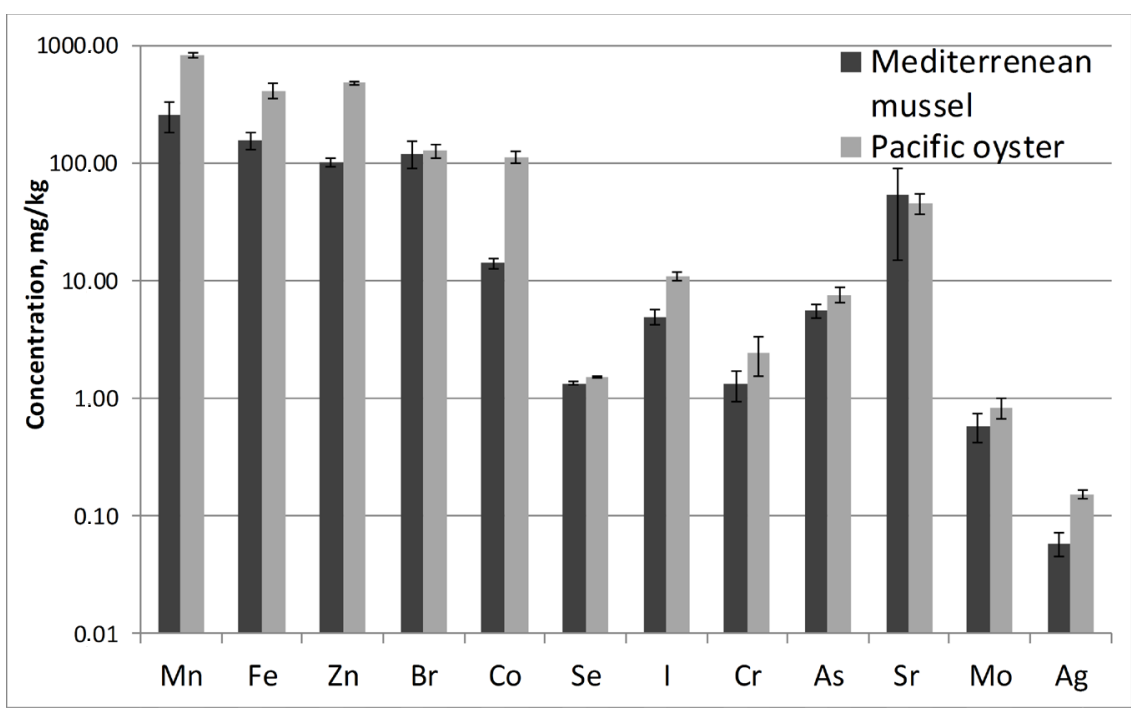

Figure 3. Contents of chemical elements in soft tissues of Mediterranean musselsand Pacificoysters. Logarithmic scale; mean and standard deviations are shown.

Another massive body of publications relate to the role the bivalves may play for environmental monitoring. In this respect the use of both cultivated and wild bivalve mollusks (including wild invasive Mediterranean mussels) as indicator organisms for monitoring of anthropogenic pollution in marine coastal waters seems to be very promising. Concentrations of some trace metals in mussels in Saldanha Bay were historically monitored on a routine basis by the Department of Environmental Affairs (DEA). The DEA "Mussel Watch Program" records concentrations of cadmium, copper, lead, zinc, iron, and manganese present in the flesh of mussels at several sites along the shoreline of the Saldanha Bay. Data from the DEA "Mussel Watch Program" show that concentrations of lead, cadmium, and zinc in mussels at the monitored sites were often above guideline limits for foodstuffs [26]. The local authorities stress that "It is vitally important that this monitoring continue in the future and that data are made available to the public for their own safety” [26]. In 1985 the Directorate of Marine and Coastal Management (MCM) of the Department of Environmental Affairs and Tourism initiated a "Mussel Watch” Program whereby mussels (including the invasive Mediterranean mussel Mytilus galloprovincialis) are collected every six months (April/May and October) from 26 coastal sites. Mussels have been collected from five stations in Saldanha Bay since 1997. Data from the Saldanha Bay MW program are currently, however, only available for the periods 1997-2001 and 2005-2007. In this respect, we compared the indicator potential of the most common and mass produced and harvested species, Pacific oyster and Mediterranean mussel.

Our present study revealed several phenomena related to the accumulation of trace elements in the tissues of farmed and wild Pacific oysters and Mediterranean mussels that contribute to our understanding of abovementioned problems as well as to the assessment of the ecological role of these non-indigenous species in the aspect of biogeochemistry.

The study revealed that both analyzed species accumulate in the soft tissues and shells a range of trace elements at detectable levels. This applies both for the essential plus suggested essential (Mn, Fe, Co, Zn, Mo, Se, I, $\mathrm{V}, \mathrm{Cr}, \mathrm{Ni}, \mathrm{Sn}$ ) and non-essential elements (Sc, As, Br, Rb, Sr, Ag, Sb, Ba, lanthanides and Ta). It is worth noting that REE (La, Ce, Sm, Eu, and Hf) were not found at detectable levels neither in the mussels nor in the oyster soft tissues (except for hafnium). These elements present only in the oyster shells. This may indicate that mussels and soft tissues of oysters are not reliable monitors for REE in marine systems. Similar phenomenon was revealed in our studies on accumulation of REE by freshwater invasive bivalve mollusks of g. Dreissena: the contents of REE in the mollusk tissues were lower than in the bottom sediments [27] [28].

Comparison of the contents of chemical elements in the shell and soft tissues of mollusks revealed that the levels of most elements are higher in the soft tissues (Figure 2 and Figure 3). Higher concentrations of these elements relate to much higher metabolic rate in the soft tissues comparing to the shells representing metabolically more inert structures. Unlike, for instance the bones in vertebrates, the shells of live bivalves do not undergo further metabolism after formation [25] and accumulated chemical elements remain at almost constant 
level. However, some elements were accumulated at larger amounts in the mussel shells ( $\mathrm{Sr}, \mathrm{Sb}$ and $\mathrm{Ba}$ in the mussel shells from both studied bays; V at Danger Bay; Mn and Br, at Saldanha Bay). In the oysters the number or such elements was even higher (Sc, V, Sr, Sb, Ba, lanthanides, and Ta). Higher shell contents of strontium and, perhaps, barium relate to relatively high affinity of these elements to calcium, which is the main "building material" for molluscan shells. Resemblances in metabolism of calcium and strontium in living beings was demonstrated quite long ago [29]. Chemically and, to a certain extent physiologically, strontium may replace calcium [30]. This explains higher shell content of strontium in both studied mollusks comparing to its level in soft tissues. The reasons of higher concentrations of other elements in the shells are unclear and need be clarified at further research.

Despite the revealed fact that concentrations of majority of essential and non-essential trace elements are higher in the studied mollusk soft tissues the assessment of the biogeochemical roles of invasions of mollusks (either in the form of farming or at naturalization in the wild) necessitates the determination of element content in both tissues. The natural predators of bivalve mollusks consume and remove only the elements accumulated in soft tissues transferring them to the higher trophic level while the elements in the shells are in fact excluded from further biological cycling (at least for a very long time). The farmed Pacific oysters and Mediterranean mussels are not subject to natural predation. The impact of natural predation on invasive Mediterranean mussels in South African waters is very low: in fact only two relatively rare predators reportedly consume invasive mussels at noticeable amounts (a gastropod, whelk Nucella cingulata and endangered bird, African black oystercatcher Haematopus moquini) [10]. As opposite, at harvesting of farmed and/or wild mollusks the elements accumulated both in the soft tissues and shells are removed from natural cycling in the ecosystem affected by harvesting. This is why at the assessment of biogeochemical role of biological invasion of bivalve mollusks the trace element concentrations should be analyzed in both types of their tissues. In addition, the analysis revealed that mollusk shells contain such non-essential and potentially toxic metals as strontium and antimony as well as REE (in oyster shells). This indicates that analysis of shells along with soft tissues is desirable for the monitoring purposes.

Comparison of the trace element contents in the Mediterranean mussels farmed in Saldanha Bay and in the wild invasive population of the Danger Bay revealed significantly higher contents of $\mathrm{Cr}, \mathrm{Mn}, \mathrm{Sr}, \mathrm{Mo}, \mathrm{Ag}, \mathrm{Fe}, \mathrm{Co}$, $\mathrm{Br}$ and $\mathrm{I}$ in the soft tissues of the latter group sample Figure 3). In our opinion these differences are determined by different environmental conditions in the compared bays: Saldanha Bay is more protected from the open ocean than the Danger Bay. The conditions (in terms of hydrodynamics and water chemistry) in the latter are more dynamic. In Saldanha Bay mussels grew in relatively stable conditions being fully submersed in the water of protected bay while the wild mussels in Danger Bay inhabit littoral rocks subject to strong hydrodynamic impact. This may result in higher metabolic rate in the wild population of invasive mollusk with subsequently higher rates of accumulation of trace elements, the majority of which are essential for mollusks. At the same differences in the environmental conditions may lead to different growth rates in compared populations. We suggest that growth rate of the Danger Bay mollusks may be lower comparing to the mussels grown at optimal conditions at the Saldanha Bay farm. Consequently, this may result in higher levels of accumulated elements in the tissues of slower-grown wild mussels. Another possible reason is the different composition of the mussels' food in these bays and, consequently, different intensities of alimentary uptake of the determined trace elements by the mussels from sampled habitats. As for higher content of zinc in the soft tissues of the mussels from Saldanha Bay this may relate to the anthropogenic pollution of the bay ecosystem originating from polymetalic ores transshipped at the facilities situated in the bay (Figure 1). The level of zinc in the Saldanha Bay mussel soft tissues (108 $\pm 0.7 \mathrm{mg} / \mathrm{kg}$ dry weight) is slightly above the legal limit of $100 \mathrm{mg} / \mathrm{kg}$ usual for many countries [31]. This also confirms that the observed higher content of zinc in the mussels from Saldanha Bay rather relates to anthropogenic pollution than to natural factors.

The present study revealed that farmed Pacific oysters accumulate both in shells and soft tissues considerably more essential and non-essential trace elements (with only a few minor exceptions-see Results) than farmed Mediterranean mussels (Figure 3). Especially striking differences concern zinc: the content of this element in oyster soft tissues is about five times higher than in the mussels. A similar phenomenon was noted by [32]: the oysters accumulated much more zinc than the mussels. In our opinion, this may reflect species-specific differences in the metabolic rates of compared mollusks and a longer period of cultivation (hence, time of growth before sampling) of oysters than that of Mediterranean mussels (on average, nine months for oysters versus six months for mussels). A study on the uptake of some trace elements in other bivalve species revealed that the or- 
ganisms are differentially selective for a range of metals and these variations might be influenced by a number of intrinsic (e.g., size, age, and sex) factors [33]. The determined level of zinc in oysters (476 $\pm 7 \mathrm{mg} / \mathrm{kg}$ ) highly exceeds the legal limit of $100 \mathrm{mg} / \mathrm{kg}$ [31] suggesting anthropogenic pollution as a main source of this metal (similarly to the mussels-see above paragraph).

The higher accumulation potential demonstrated in Pacific oysters suggests that this species at similar biomass may have stronger effect upon biogeochemical cycling of trace elements than farmed and invasive wild Mediterranean mussels. In addition, oysters seem to be a better biomonitor for trace elements than mussels. In a study on another group of bivalves the authors draw a similar conclusion: the oysters Crassostrea rhizophorae (close relative of Pacific oyster analyzed in the present study) were particularly recommended as biomonitors given their strong accumulation patterns for many trace metals, their large size and their local abundance [34].

Higher levels of essential elements in the oyster soft tissues (i.e. in the edible part of the mollusk) indicate that this species has higher nutritional value for humans than farmed Mediterranean mussels. At the same time, this indicates the necessity for continuing regular monitoring of metal burdens in the edible part of farmed oysters. Higher contents of majority of essential elements in the soft tissues of wild invasive mussels comparing to the farmed specimens of this species suggest higher nutritional value of wild mussels particularly. Widespread and extremely high biomass of this invasive species along the South African coast represents a good source of highly nutritionally valuable seafood. Harvesting of wild mussels may be very profitable and cost-effective addition to farming of this mollusk on rather limited coastal areas appropriate for mariculture.

In general, the contents of majority of trace elements observed in the present study in the comparison to the contents reported in other papers and legal limits adopted for toxic metals may be considered as relatively low compared to contents reported in other papers and legal limits adopted for toxic metals. The only exception concerns zinc: its content in Mediterranean mussels is very close to the legal limits; in Pacific oysters, the tissue content of this metal is alarming really.

The present study confirms that both species of bivalve mollusks, farmed Pacific oysters and farmed and wild invasive Mediterranean mussels are potent bioaccumulators of a range of trace elements. This suggests that at high biomasses of both farmed and especially established wild invasive mollusks their effect on the biogeochemical cycling of various trace elements (except REE) may be very strong. We plan to continue studies in this direction including clarification of the temporal patterns of accumulation dynamics. The data presented here may serve for drawing the balance of chemical elements in the marine ecosystems affected by biological invasions of bivalve mollusks either in the form of framing or unintentional introduction of alien species. The study also demonstrated that non-indigenous Mediterranean mussels and, especially Pacific oysters may serve as good biomonitors for trace elements. Finally, both alien species, farmed and wild, provide nutritionally-valuable seafood for human consumption.

\section{Conclusions}

Farmed Pacific oysters along with farmed and wild invasive Mediterranean mussels producing high biomasses at the South African coastal waters accumulate considerable amounts of various trace elements. The contents of the majority of elements in the soft tissues of both species are higher than in the shells.

The tissues of wild invasive Mediterranean mussels contain higher levels of a range of trace elements (especially essential elements) comparing to farmed mussels, which indicates differences in the environmental conditions in studied areas.

The tissues of Pacific oysters contain much higher levels of almost all elements studied compared to the tissues of Mediterranean mussels, indicating differences in their metabolic rates, ages and, on the other hand higher richness of edible parts of oysters in the essential micronutrients.

Higher content of zinc in the mussels and oysters from Saldanha Bay may evidence anthropogenic pollution of the bay's ecosystem by this metal, which necessitates continued monitoring of levels of potentially toxic metals. Both alien species, and especially Pacific oysters, may serve as reliable biomonitors for trace elements in marine ecosystems. Both species are rich in essential elements and provide nutritionally-valuable seafoods.

The studied alien bivalve mollusks, accumulating large amounts of trace elements and producing extremely high biomass both at the sea farms 'inserted" in nature and in the wild invasive population, strongly affect the biogeochemical cycling of a range of chemical elements. The quantitative assessment of this effect is worthy of further research. 


\section{Acknowledgements}

The authors acknowledge the JINR-SA (NRF) grant for 2012-2014.

\section{References}

[1] NDA (2012)

http://www.nda.agric.za/doadev/fisheries/03_areasofwork/-Aquaculture/AquaAndEnvironment/C\%20gigas\%20BRBA \%2012.12.12.pdf

[2] DAFF (2012) Department of Agriculture, Forestry and Fisheries. Biodiversity Risk and Benefit Assessment (BRBA) of Alien Species in Aquaculture in South Africa South African Molluscan Shellfish Monitoring \& Control Programme Annual Report 2011.

http://www.anchorenvironmental.co.za/Documents/Pdfs/DAFF\%20Biodiversity\%20Risk\%20and\%20Benefit\%20Asse ssment\%20\%28BRBA\%29\%20/C\%20gigas\%20BRBA\%2012.12.12.pdf

[3] Olivier, D., Heinecken, L. and Jackson, S. (2013) Mussel and Oyster Culture in Saldanha Bay, South Africa: Potential for Sustainable Growth, Development and Employment Creation. Food Security, 5, 251-267

http://link.springer.com/article/10.1007\%2Fs12571-013-0244-1\#page-1 http://dx.doi.org/10.1007/s12571-013-0244-1

[4] Naylor, R.L., Williams, S.L. and Strong, D.R. (2001) Aquaculture-A Gateway for Exotic Species. Science, 294, 1655-1656. http://dx.doi.org/10.1126/science.1064875

[5] Stenton-Dozey, J., Probyn, T. and Busb, A. (2001) Impact of Mussel Raft-Culture on Benthic Macrofauna, in Situ Oxygen Uptake, and Nutrient Fluxes in Saldanha Bay, South Africa. Canadian Journal of Fish and Aquaculture Science, 58, 1021-1031. http://science.report/author/j-stenton-dozey/

[6] Wolff, W.J. and Reise, K. (2002) Oyster Imports as a Vector for the Introduction of Alien Species into Northern and Western European Coastal Waters. In: Leppakoski, E., Gollasch, S. and Olenin, S., Eds., Invasive Aquatic Species of Europe, Kluwer Academic Publishers, The Netherlands, 193-205.

https://www.rug.nl/research/portal/publications/invasive-aquatic-species-of-europe--distribution-impacts-and-manage ment\%28eb382062-170f-4077-81db-c8b022717bab\%29.html http://dx.doi.org/10.1007/978-94-015-9956-6 21

[7] Haupt, T.M., Griffiths, C.L., Robinson, T.B. and Tonin, A.F.G. (2010) Oysters as Vectors of Marine Aliens, with Notes on Four Introduced Species Associated with Oyster Farming in South Africa. African Zoology, 45, 52-62. http://www.bioone.org/doi/abs/10.3377/004.045.0101 http://dx.doi.org/10.3377/004.045.0101

[8] Griffiths, C.L., Hockey, P.A.R., van Erkom Schurink, C. and Le Roux, P.J. (1992) Marine Invasive Aliens on South African Shores: Implications for Community Structure and Trophic Functioning. In: Payne, A.I.L., Brink, K.H., Mann, K.H. and Hilborn, S.R., Eds., Benguela Trophic Functioning, African Journal of Marine Sciences, 12, 713-722.

[9] Hanekom, N. and Nel, P. (2002) Invasion of Sandflats in Langebaan Lagoon, South Africa, by the Alien Mussel Mytilus galloprovincialis: Size, Composition and Decline of the Populations. African Zoology, 37, 197-208. http://reference.sabinet.co.za/document/EJC17835

[10] Robinson, T.B., Griffiths, C.L., McQuaid, C.D. and Rius, M. (2005) Marine Alien Species of South Africa—Status and Impacts. African Journal of Marine Science, 27, 297-306. http://planet.botany.uwc.ac.za/nisl/invasives/refs/robinson\%2520et\%2520al.\%25202005.pdf http://dx.doi.org/10.2989/18142320509504088

[11] Ren, J.S., Ross, A.H. and Schiel, D.R. (2000) Functional Descriptions of Feeding and Energetics of the Pacific Oyster Crassostrea gigas in New Zealand. Marine Ecology Progress, 208, 119-130. http://www.int-res.com/articles/meps/208/m208p119.pdf http://dx.doi.org/10.3354/meps208119

[12] Neal, C. (2007) Rare Earth Element Concentrations in Dissolved and Acid Available Particulate Forms for Eastern UK Rivers. Hydrology and Earth System Science, 11, 313-327. http://www.hydrol-earth-syst-sci.net/11/313/2007/hess-11-313-2007.pdf http://dx.doi.org/10.5194/hess-11-313-2007

[13] Grawunder, A. and Merten, D. (2012) Rare Earth Elements in Acidic Systems-Biotic and Abiotic Impacts. In: Kothe, E. and Varma, A., Eds., Bio-Geo Interactions in Metal-Contaminated Soils, Springer, New York, 81-97. http://link.springer.com/book/10.1007/978-3-642-23327-2 http://dx.doi.org/10.1007/978-3-642-23327-2_4

[14] Weltje, J. (2003) Bioavailability of Lanthanides to Freshwater Organisms, Speciation, Accumulation and Toxicity. Thesis of Dissertation, DUP Science, Delft, 1-184. 
[15] Goldberg, E.D. (1975) The Mussel Watch: A First Step in Global Marine Monitoring. Marine Pollution Bulletin, 6, 111-114. http://dx.doi.org/10.1016/0025-326X(75)90271-4

[16] Klumpp, D.W. and Burdon-Jones, C. (1982) Investigations of the Potential of Bivalve Mollusks as Indicators of Heavy Metal Levels in Tropical Marine Waters. Australian Journal of Marine and Freshwater Research, 33, 285-300. http://dx.doi.org/10.1071/MF9820285

[17] Goldberg, E.D. and Bertine, K.K. (2000) Beyond the Mussel Watch: New Directions for Monitoring Marine Pollution. The Science of the Total Environment, 247, 165-174. http://www.ncbi.nlm.nih.gov/pubmed/10803545 http://dx.doi.org/10.1016/s0048-9697(99)00488-x

[18] Frontasyeva, M.V. (2011) Neutron Activation Analysis for the Life Sciences: A Review. Physics of Particles and Nuclei, 42, 332-378. http://www.springerlink.com/content/f836723234434m27 http://dx.doi.org/10.1134/s1063779611020043

[19] Pavlov, S.S., Dmitriev, A.Y., Chepurchenko, I.A. and Frontasyeva, M.V. (2014) Automation System for Measurement of Gamma-Ray Spectra of Induced Activity for Neutron Activation Analysis at the Reactor IBR-2 of Frank Laboratory of Neutron Physics at the Joint Institute for Nuclear Research. Physics of Elementary Particles and Nuclei, 11, 737-742. http://www1.jinr.ru/Pepan_letters/panl_2014_6/06_pavl.pdf

[20] Beliaeff, B., O’Connor, T.O. and Claisse, D. (1998) Comparison of Chemical Concentrations in Mussels and Oysters from the United States and France. Environmental Monitoring and Assessment, 49, 87-95. http://link.springer.com/article/10.1023\%2FA\%3A1005766321323 http://dx.doi.org/10.1023/A:1005766321323

[21] Vazquez, F., Aguilera, G., Delgado, D. and Marquez, A. (1990) Trace and Heavy Metals in the Oyster Crassostrea virginica, San Andres Lagoon, Tamaulipas, Mexico. Bulletin of Environmental Contamination and Toxicology, 45, 907-914. http://link.springer.com/article/10.1007\%2FBF01701092 http://dx.doi.org/10.1007/BF01701092

[22] Watling, H.R. and Watling, R.J. (1982) Metal Concentrations in Oysters from the Southern African Coast. Bulletin of Environmental Contamination and Toxicology, 28, 460-466. http://link.springer.com/article/10.1007\%2FBF01607711\#page-1 http://dx.doi.org/10.1007/BF01607711

[23] Martincié, D., Nürnberg, H.W., Stoeppler, M. and Branica, M. (1984) Bioaccumulation of Heavy Metals by Bivalves from Lim Fjord (North Adriatic Sea). Marine Biology, 81, 177-188. http://dx.doi.org/10.1007/BF00393116

[24] Stankovic, S., Jovic, M., Stankovic, A.R. and Katsikas, L. (2012) Heavy Metals in Seafood Mussels. Risk for Human Health. In: Lichthouse, E., Schwarzbauer, J. and Robert, D., Eds., Environmental Chemistry for a Sustainable World, Nanotechnology and Health Risk, Springer, Dordrecht, 311-373.

[25] Wilbur, K.W. (1972) Shell Formation in Mollusks. In: Florkin, M. and Scheer, B.T., Eds., Chemical Zoology, Volume 7, Academic Press, New York and London, 103-146.

[26] Bay, S. and Lagoon, L. (2012) State of the Bay 2011. Technical Report, Saldanha Bay Water Quality Trust, 1-271.

[27] Pavlov, D.F., Frontasyeva, M.V., Pavlov, S.S. and Pankratova, Y.S. (2005) Distribution of Trace Elements in Freshwater Ecosystem Compartments of Man-Made Rybinsk Reservoir (Central Russia) Using Epithermal Neutron Activation Analysis. “Ovidius University” Annals of Chemistry, 16, 72-75.

[28] Goryaynova, Z.I., Frontasyeva, M.V., Pavlov, D.F. and Pankratova, Y.V. (2007) Chemical Composition Study of the Rybinsk Reservoir Ecosystem Using NAA. In: Granja, C., Leroy, C. and Stekl, I., Eds., Proceedings of Summer School “Nuclear Physics Methods and Accelerators in Biology and Medicine-2007”, American Institute of Physics, New York, 226-227. http://dx.doi.org/10.1063/1.2825789

[29] Posin, D.Q. (1942) Investigations with Radioactive Strontium, Phosphorus and Iron. Proceedings of Montana Academy of Sciences, 3, 10-15.

[30] Pors Nielsen, S. (2004) The Biological Role of Strontium. Bone, 35, 583-588. http://www.thebonejournal.com/article/S8756-3282\%2804\%2900181-4/abstract http://dx.doi.org/10.1016/j.bone.2004.04.026

[31] Irwin, R., van Mouverick, M., Stevens, L., Seese, M. and Basham, W. (1997) In Environmental Contaminants Encyclopedia. National Park Service, Water Resources Division, Fort Collins. http://www.nature.nps.gov/hazardssafety/toxic/uranium.pdf

[32] Joiris, C. (2014) Ecotoxicology of Stable Pollutants in African Marine Ecosystems. UNESCO_Encyclopedia of Life Support Systems (EOLSS), Volume 1, Area Studies-Africa (Regional Sustainable Development Revue) http://www.eolss.net/outlinecomponents/Regional-Sustainable-Development-Review-Africa.aspx

[33] Sarkar, S.K., Cabral, E., Chatterjee, M., Cardoso, I., Bhattacharya, A.K. and Satrathy, K.K. (2008) Biomonitoring of Heavy Metals Using the Bivalve Molluscs in Sunderban Mangrove Wetland, Northeast Coast of Bay of Bengal (India): 
Possible Risks to Human Health. CLEAN—Soil, Air, Water, 36, 187-194.

http://www.researchgate.net/publication/216407928_Biomonitoring_of_Heavy_Metals_Using_the_Bivalve_Molluscs in_Sunderban_Mangrove_Wetland_Northeast_Coast_of_Bay_of_Bengal_\%28India\%29_Possible_Risks_to_Human_ Health

http://dx.doi.org/10.1002/clen.200700027

[34] Kesavan, K., Murugan, A., Tesan, V.V. and Vejay Kumar, B.S. (2013) Heavy Metal Accumulation in Mollusks and Sediment from Uppanar Estuary, South East Coast of India. Thalassas, 29, $15-21$.

http://thalassas.webs.uvigo.es/Thalassas\%2029\%282\%29/002\%20Thalassas\%2029\%282\%29.pdf 